\title{
Synthesis of a deuterated probe for the confocal Raman microscopy imaging of squalenoyl nanomedicines
}

\author{
Eric Buchy ${ }^{1}$, Branko Vukosavljevic ${ }^{2,3}$, Maike Windbergs ${ }^{2,3}$, Dunja Sobot ${ }^{1}$, \\ Camille Dejean ${ }^{4}$, Simona Mura ${ }^{1}$, Patrick Couvreur ${ }^{1}$ and Didier Desmaële ${ }^{* 1}$
}

\author{
Full Research Paper \\ Address: \\ ${ }^{1}$ Institut Galien (UMR CNRS 8612) Faculté de Pharmacie, Université \\ Paris-Sud, 5, rue Jean-Baptiste Clément, 92296 Châtenay-Malabry, \\ France, ${ }^{2}$ Department of Drug Delivery, Helmholtz Centre for Infection \\ Research and Helmholtz Institute for Pharmaceutical Research \\ Saarland, Campus E8.1, 66123 Saarbruecken, Germany, \\ ${ }^{3}$ Biopharmaceutics and Pharmaceutical Technology, Saarland \\ University, Campus A 4.1, 66123 Saarbruecken, Germany and \\ ${ }^{4} \mathrm{BIOCIS}$ (UMR CNRS 8076) Faculté de Pharmacie, Université \\ Paris-Sud, 5, rue Jean-Baptiste Clément, 92296 Châtenay-Malabry, \\ France \\ Email: \\ Didier Desmaële* - didier.desmaele@u-psud.fr \\ * Corresponding author \\ Keywords: \\ deuterium labelling; nanomedicine; Raman spectroscopy; Shapiro \\ reaction; squalene

\begin{abstract}
Beilstein J. Org. Chem. 2016, 12, 1127-1135.
\end{abstract} \\ doi:10.3762/bjoc.12.109 \\ Received: 25 January 2016 \\ Accepted: 19 May 2016 \\ Published: 06 June 2016 \\ Associate Editor: S. C. Zimmerman \\ ๑) 2016 Buchy et al; licensee Beilstein-Institut. \\ License and terms: see end of document.
}

\begin{abstract}
The synthesis of $\omega$-di-(trideuteromethyl)-trisnorsqualenic acid has been achieved from natural squalene. The synthesis features the use of a Shapiro reaction of acetone- $d_{6}$ trisylhydrazone as a key step to implement the terminal isopropylidene- $d_{6}$ moiety. The obtained squalenic acid- $d_{6}$ has been coupled to gemcitabine to provide the deuterated analogue of squalenoyl gemcitabine, a powerful anticancer agent endowed with self-assembling properties. The Raman spectra of both deuterated and non-deuterated squalenoyl gemcitabine nanoparticles displayed significant Raman scattering signals. They revealed no differences except from the deuterium peak patterns in the silent spectral region of cells. This paves the way for label-free intracellular trafficking studies of squalenoyl nanomedicines.
\end{abstract}

\section{Introduction}

Application of nanotechnology to medicine holds promises to profoundly impact healthcare especially to treat severe diseases such as cancer, intracellular infections, neurodegenerative diseases, etc. Indeed, the nanometric size confers to drug delivery systems unique properties which improve the pharma- cokinetics and the biodistribution of many active compounds, thus increasing specificity, therapeutic efficacy and reducing systemic exposure and toxicity $[1,2]$. In recent years, many drug delivery systems have been developed covering all aspects of medicine. Among them, lipid drug conjugates (LDC) were 
especially developed for the delivery of hydrophilic drugs by covalent coupling with lipid components $[3,4]$. In this context we recently found that the chemical conjugation of squalene, a natural and biocompatible triterpene, to a drug led to the formation of a prodrug that spontaneously self-assembled as nanoparticles in water. The advantage of this approach is a very high drug loading into the nanoparticles and the absence of burst release [5]. The proof of concept of this method has been done using gemcitabine (2), an anticancer chemotherapeutic drug used to treat various solid tumors [6]. Remarkably, the squalene conjugate of gemcitabine (GemSQ) self-assembled in aqueous media as nanoassemblies of around $100 \mathrm{~nm}$ mean particle size with a low polydispersity index. The nanosuspension exhibited impressively greater anticancer activity than free gemcitabine against different experimental tumor models [7-11] overcoming the main drawbacks of the parent drug such as its short biological half-life and its low intracellular diffusion $[12,13]$. Following these initial results, the squalenoylation method was extended to other nucleoside analogues such as antiretroviral agents, ddC, ddI and AZT [14] and to siRNA oligonucleotides [15]. More notably, squalenoylation of adenosine and the subsequent formation of NAs, allowed prolonged circulation of this nucleoside, providing neuroprotection in mice with induced focal cerebral ischemia and in rats undergoing spinal cord injury [16]. Interestingly, the "squalenisation platform" initially developed with highly hydrophilic therapeutics has been further extended to hydrophobic drugs such as betalactam antibiotics [17], paclitaxel [18], indolinone kinase inhibitors [19] or doxorubicin [20].

For the elucidation of the mechanisms involved in the efficacy of these promising nanomedicines, the precise knowledge regarding the cellular uptake, the intracellular localization and the determination of the subcellular interactions and trafficking is crucial. To fulfill this task, radioactive labeling or fluorescent probes have been thoroughly used. For example, the subcellular localization of the ${ }^{3} \mathrm{H}$-radiolabeled GemSQ conjugate has been evaluated by micro-autoradiography coupled to confocal imaging of fluorescently labeled cellular structures [21]. A dual radioactive labeling ${ }^{3} \mathrm{H},{ }^{14} \mathrm{C}$ has been taken into profit to study the pharmacokinetics, the biodistribution and the metabolism of squalenoyl adenosine nanoparticles [22]. Nevertheless, the synthesis of labeled compounds is chemically challenging, expensive and submitted to drastic regulation rules. In addition, the use of fluorescent probes requires the covalent binding of large dye molecules (bodipy, cyanine, rhodamine etc, ...) to the drug conjugate, thus potentially modifying its physicochemical profile as well as the in vivo fate and the pharmacological activity. A simple encapsulation of an amphiphilic fluorochrome in LDC nanoparticles can be used as far as the colloidal stability of the nanocarrier is preserved, but cannot address the intracel- lular tracking of the loaded drug after carrier disassembling. Thus, specific tools such as fluorescence resonance energy transfer (FRET) and fluorescence quenching, have been developed to study the stability of nanoparticles [23].

In this context, Raman spectroscopy is an interesting technique which is based on the detection of scattered laser light upon irradiating the sample. Nevertheless, because of the low intensity of the Raman scattering, efficient in vivo confocal Raman microspectroscopy of cells had to wait until laser technology and mathematical image processing have made enough progress $[24,25]$. In contrast to fluorescence spectroscopy, Raman spectroscopy is label-free, as its scattering effect is unique for a specific molecular structure. Raman spectra of cells usually consist of spectral contributions from proteins, lipids and polysaccharides. For the simultaneous detection of both the drug and the cell components with the aim to investigate how they interact, a significant spectral contrast is required. Unfortunately, it can be hardly achieved when dealing with low drug concentrations or biological-like structures such as peptide drugs or nucleoside analogues. To overcome this issue, deuterium can be introduced to a sample molecule, as it exhibits a significant Raman signal at around $2200 \mathrm{~cm}^{-1}$, which is in a so called "silent region" (1800-2800 $\mathrm{cm}^{-1}$ ) of most biological molecules. For example as early as 1976 , specifically deuterated stearic acids have been used by Sunder et al. in Raman studies and Stiebing et al. studied the uptake of arachidonic acid in human macrophages [26,27]. Furthermore, deuterium does not change the physicochemical properties and thus does not perturb the structure of the described NAs. Consequently, deuterated squalenic acid is expected to be excellent as bioorthogonal Raman tag for squalene-based NAs. Since the Raman signal intensity is expected to increase with the number of deuterium atoms in the same chemical environment, we have undertaken an effort directed towards the synthesis of $\omega$-di-(trideuteromethyl)trisnorsqualenic acid $\left(\mathrm{SQCO}_{2} \mathrm{H}-d_{6}, \mathbf{1}\right)$ bearing six deuterium atoms on a non-labile position via isotopic exchange. We disclose herein the synthesis of this deuterated Raman probe from natural squalene, its coupling with gemcitabine and the Raman spectra of the deuterated GemSQ nanoassemblies, opening the way to perform intracellular imaging of squalenoyl nanomedicine (Figure 1).

\section{Results and Discussion Chemical synthesis of squalenic acid- $d_{6}$ and GemSQ- $d_{6}$ conjugate}

In a first approach we decided to explore the selective Wittig mono-olefination of dialdehyde 5 readily accessible from the known 2,3;22,23-epoxysqualene (7) [28]. As depicted in Scheme 1, the synthetic sequence began with the treatment of squalene with two equivalents of NBS in a water/THF mixture. 


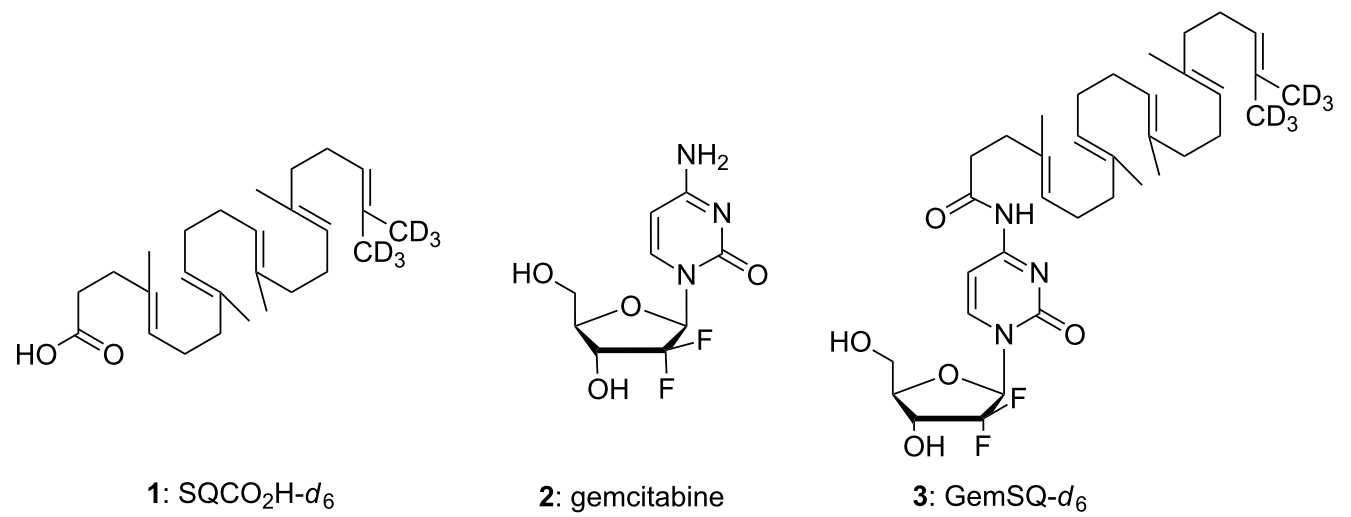

Figure 1: Structure of squalenic acid- $d_{6}$, gemcitabine and GemSQ- $d_{6}$ conjugate.

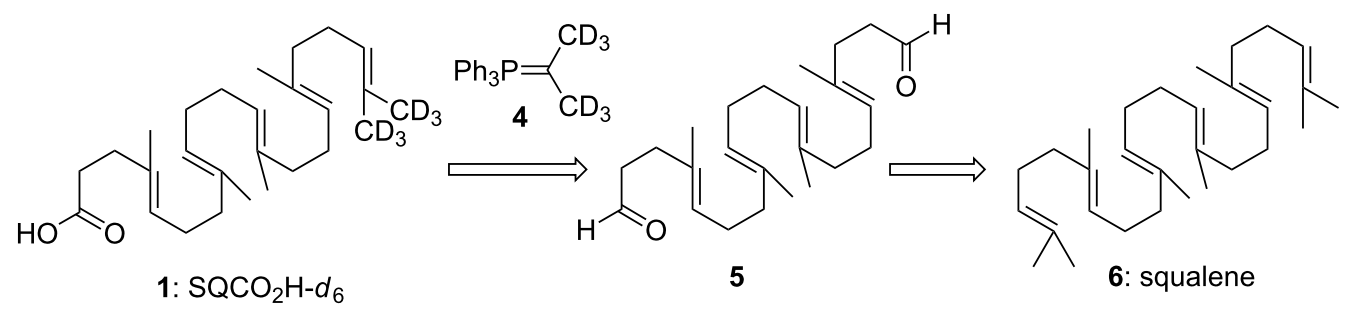

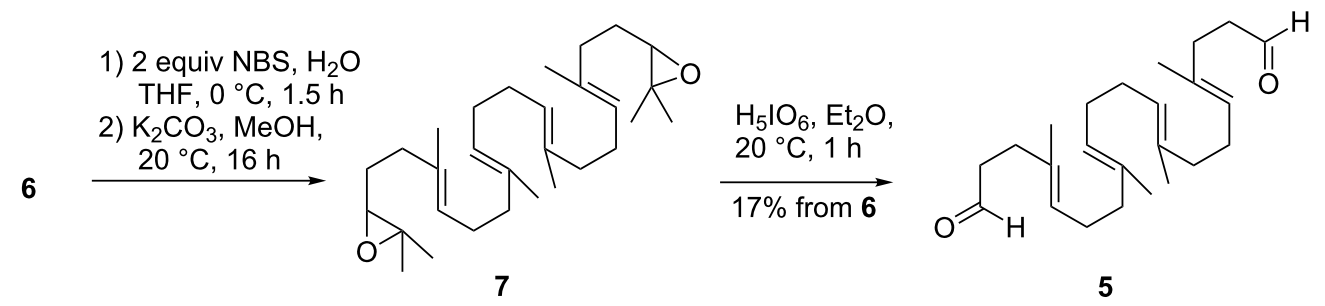

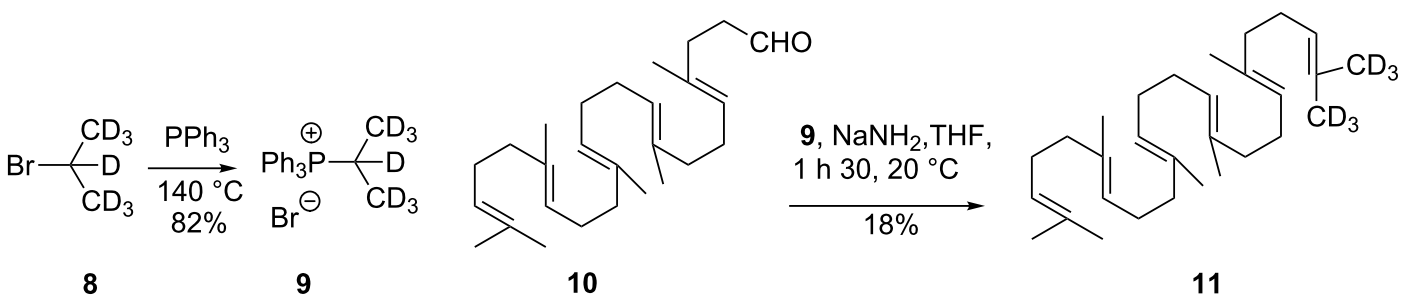

Scheme 1: Retrosynthetic route to $S Q \mathrm{CO}_{2} \mathrm{H}-d_{6}(1)$ and synthetic routes for the preparation of dialdehyde 5 and squalene- $d_{6} 11$.

After separation of the bis-bromohydrin from the monoproduct, potassium carbonate treatment gave the expected diepoxide 7. Oxidative cleavage with periodic acid provided the corresponding dialdehyde 5 in $17 \%$ overall yield from squalene. The perdeuterated phosphonium salt 9 was obtained by simple condensation of commercially available 2-bromopropane- $d_{7}$ (8) with triphenylphosphine [29]. To our surprise, condensation of dialdehyde 5 with one equivalent of the ylide $4(9, n$-BuLi,
THF, $-78{ }^{\circ} \mathrm{C}$ ) did not afford any amount of the desired deuterated olefin but only polar material that could not be characterized. In an attempt to find more efficient reaction conditions, we investigated this reaction using the simple aldehyde $\mathbf{1 0}$ as a model compound, easily accessible from squalene according to the van Tamelen procedure [30]. The condensation of ylide 4 with $\mathbf{1 0}$ seemed to be an easy task, but many well-established procedures using various bases ( $n-\mathrm{BuLi}, \mathrm{LiHMDS}, \mathrm{NaH} /$ 
DMSO, PhLi) [29,31,32] gave only intractable materials. We finally found that the treatment of $\mathbf{1 0}$ with the "instant ylide mixture" of Schlosser made by grinding a solid mixture of 9 and $\mathrm{NaNH}_{2}$ [33] delivered the desired squalene- $d_{6}(\mathbf{1 1})$ although in a low $18 \%$ yield. However, when applied to the dialdehyde $\mathbf{5}$ this procedure failed to give the expected Wittig adduct.

Whatever the origin of this problem, we decided to explore a new strategy based on a more nucleophilic deuterated synthon. In this regard we targeted prop-1-en-2-yllithium- $d_{5}(\mathbf{1 5})$ which is easily accessible through the Shapiro reaction of sulfonylhydrazone of acetone- $d_{6}[34,35]$. Thus condensation of trisylhydrazine with acetone- $d_{6}(99.8 \% \mathrm{D})$ gave the expected hydrazone 14 in 55\% yield. To our delight, upon treatment with two equivalents of $n$ - BuLi and warming to $0{ }^{\circ} \mathrm{C}$, the trisylhydrazone 14 afforded the vinyllithium reagent 15 (along with $\mathrm{N}_{2}$ and the trisyl anion) which upon condensation with squalenaldehyde $\mathbf{1 0}$ furnished the desired allylic alcohol $\mathbf{1 6}$ in 59\% yield. Reduction of the hydroxy group of $\mathbf{1 6}$ was straightforwardly achieved in $47 \%$ yield by treatment with a large excess of thionyl chloride followed by $\mathrm{LiAlD}_{4}$ reduction [36]. Having secured an efficient method to reinstall the isopropylidene end- group, we turned our attention to the application of this method to a two-end functionalized squalene derivative. However, when applied to dialdehyde 5 the Shapiro reaction led to a mixture of starting material (30\%), allylic alcohol 18 (15\%) and diol 17 (20\%). This result could not by improved using reverse addition conditions (Scheme 2). Therefore, selective monoprotection of the dialdehyde $\mathbf{5}$ was next attempted. Unfortunately, treatment of the latter either with ethylene glycol or 2,2dimethylpropandiol gave a mixture of di- and monoacetal whatever the conditions, as a new example of the lack of chemoselectivity of this long polyisoprenyl chain derivatives.

The differentiation of both ends of squalene was thus performed starting from trisnorsqualenaldehyde 10. Protection of $\mathbf{1 0}$ as 2,2-dimethyl-1,3-dioxane derivative gave 19 in 96\% yield which was further elaborated into aldehyde 20 in $16 \%$ overall yield according to the three-step van Tamelen sequence (i. NBS, THF, $\mathrm{H}_{2} \mathrm{O}$; ii. $\mathrm{K}_{2} \mathrm{CO}_{3}, \mathrm{MeOH}$; iii. $\mathrm{H}_{3} \mathrm{IO}_{6}, \mathrm{Et}_{2} \mathrm{O}$ ) [30]. Interestingly enough, the 1,3-dioxane group survived the strongly acidic conditions of the oxidative cleavage. We next turned to the elaboration of the isopropylidene- $d_{6}$ moiety. In the event, the Shapiro reaction using trisylhydrazide $\mathbf{1 4}$ delivered the expected allylic alcohol 21 in 70\% yield. The latter afforded
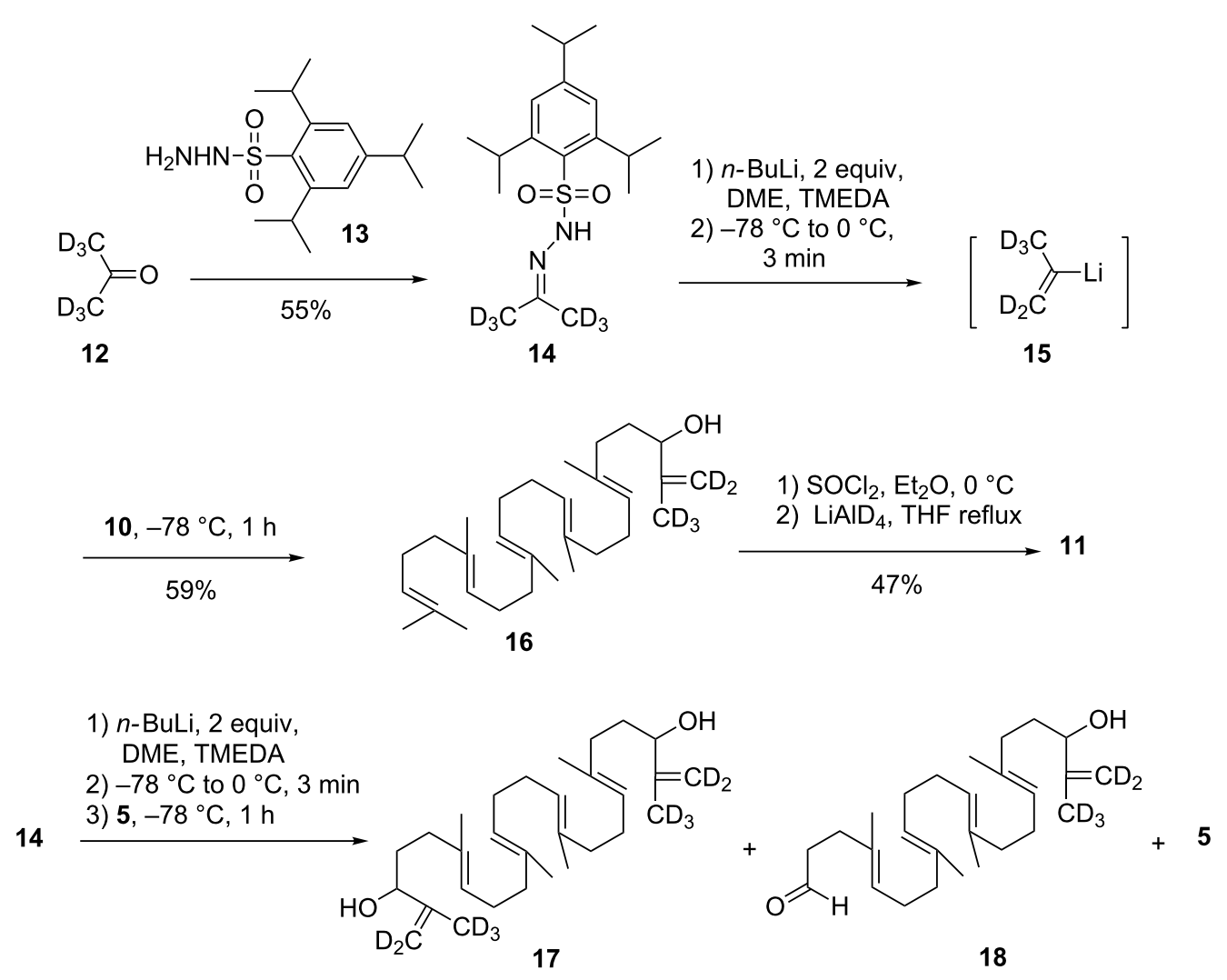
the deuterated ketal $\mathbf{2 2}$ in 52\% yield, upon sequential treatment with thionyl chloride and $\mathrm{LiAlD}_{4}$ as described above. With the success of the implementation of the terminal deuterated isopropylidene group we turned our attention to the deprotection of the ketal and the oxidation of the aldehyde group. This seemingly trivial task, turned out to be unexpectedly challenging. All conditions tried $\left(\mathrm{HCl} 3 \mathrm{~N}\right.$, THF, $20{ }^{\circ} \mathrm{C} ; \mathrm{HCl} 3 \mathrm{~N}$, THF, reflux; $\mathrm{HCl} 6 \mathrm{~N}$, dioxane, $20{ }^{\circ} \mathrm{C} ; \mathrm{HCO}_{2} \mathrm{H}$, reflux; $\mathrm{FeCl}_{3} \cdot 6 \mathrm{H}_{2} \mathrm{O} / \mathrm{SiO}_{2}$ [37], Jones reagent) either let the starting material unchanged or induced a complete decomposition. Even treatment with 1,2ethanedithiol in the presence of $\mathrm{BF}_{3} \cdot \mathrm{OEt}_{2}$ failed to give the corresponding thioketal [38]. These results clearly showed that another protecting group must be used, avoiding the use of an acidic catalyst that triggered the cyclization cascade of the polyisoprenyl chain (Scheme 3).

Despite this setback, the synthetic route seemed suitable to produce the desired material. Thus, the synthetic pathway described above was reimplemented starting from tertbutyldiphenylsiloxysqualene $\mathbf{2 3}$ readily obtained in $85 \%$ yield from squalenaldehyde $\mathbf{1 0}$ by $\mathrm{NaBH}_{4}$ reduction followed by protection with tert-butyldiphenylsilyl chloride. Functionalisation of the opposite extremity of the polyisoprenoid chain using the van Tamelen sequence (i. 1 equiv NBS, THF, $\mathrm{H}_{2} \mathrm{O}$; ii. $\mathrm{K}_{2} \mathrm{CO}_{3}, \mathrm{MeOH}$; iii. $\mathrm{H}_{3} \mathrm{IO}_{6}, \mathrm{Et}_{2} \mathrm{O}$ ) afforded the aldehyde $\mathbf{2 6}$ in $16 \%$ overall yield. Uneventfully, the Shapiro reaction with trisylhydrazone 14 produced the allylic alcohol 27. Thionyl chloride treatment followed by $\mathrm{LiAlD}_{4}$ reduction delivered directly the alcohol $\mathbf{2 8}$ in $41 \%$ yield through concomitant reduction of the intermediate allylic chloride and cleavage of the silyl protecting group. The reductive cleavage of tert-butyldiphenylsilyl ethers by $\mathrm{LiAlH}_{4}$ has been previously noticed [39]. Jones oxidation straightforwardly completed the synthesis of $\mathrm{SQCO}_{2} \mathrm{H}-d_{6} \mathbf{1}$. Mass spectral analysis confirmed the presence of the six deuterium atoms $(\mathrm{m} / z=405.3631$ for $\left.\left[\mathrm{C}_{27} \mathrm{H}_{37} \mathrm{D}_{6} \mathrm{O}_{2}{ }^{-}\right]\right)$along a small amount $(\sim 5 \%)$ of $\mathrm{SQCO}_{2} \mathrm{H}-d_{5}$. GemSQ- $d_{6} 3$ was next synthetized using activation with ethyl chloroformate as previously reported [7]. However, to optimize the process a large excess of gemcitabine was used in the reaction to increase the yield to $72 \%$ in respect of the more valuable $\mathrm{SQCO}_{2} \mathrm{H}-d_{6}$ (Scheme 4).

\section{Nanoparticle formulation of the GemSQ- $d_{6}$ conjugate and Raman spectroscopy}

The GemSQ and GemSQ- $d_{6}$ nanoassembly suspensions $\left(2 \mathrm{mg} \cdot \mathrm{mL}^{-1}\right)$ were prepared in a single step by nanoprecipitation of an ethanolic solution $\left(2-4 \mathrm{mg} \cdot \mathrm{mL}^{-1}\right)$ in milli-Q water [7]. After spontaneous formation of the NAs the organic solvent was evaporated under vacuum (Figure 2A). Single Raman spectra of the raw substances as well as of the particles were recorded (Figure 2B). As depicted in Figure 2C and Figure 2D, the Raman spectra of the deuterated and non-deuterated compounds revealed no differences except the deuterium peaks in the silent region.

\section{Conclusion}

A synthesis of squalenic acid- $d_{6}$ was developed through the Shapiro reaction of the sulfonylhydrazone of acetone- $d_{6}$ with an $\omega$-silyloxysqualene aldehyde derivative followed by a regioselective reduction of the obtained allylic alcohol. This material was obtained from natural squalene in $0.6 \%$ yield over 12 steps. The synthesized deuterated squalenic acid was coupled to gemcitabine to provide the corresponding deuterated squalenoyl conjugate. Raman spectra of the nanoassemblies made of this conjugate were recorded, showing significant Raman peaks in the silent region of the cells thus making this material a poten-

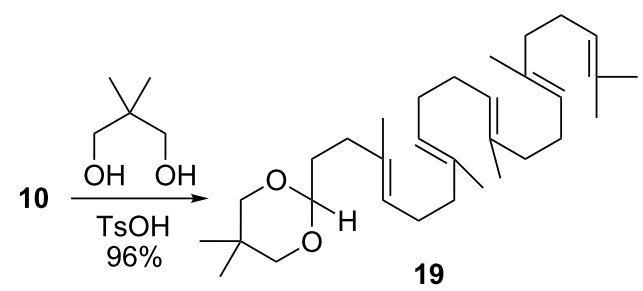

1) $\mathrm{NBS}, \mathrm{THF}$, water,
$0^{\circ} \mathrm{C}, 1 \mathrm{~h} 30$
2) $\mathrm{K}_{2} \mathrm{CO}_{3}, \mathrm{MeOH}$,
$20^{\circ} \mathrm{C}, 16 \mathrm{~h}$
3) $\mathrm{H}_{5} \mathrm{O}_{6}, \mathrm{Et} \mathrm{E}_{2} \mathrm{O}$,
$20^{\circ} \mathrm{C}, 1 \mathrm{~h}$
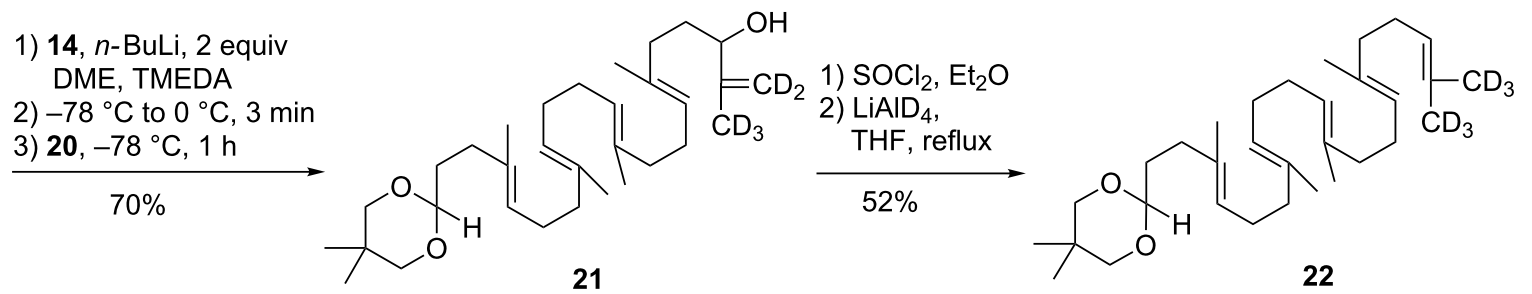


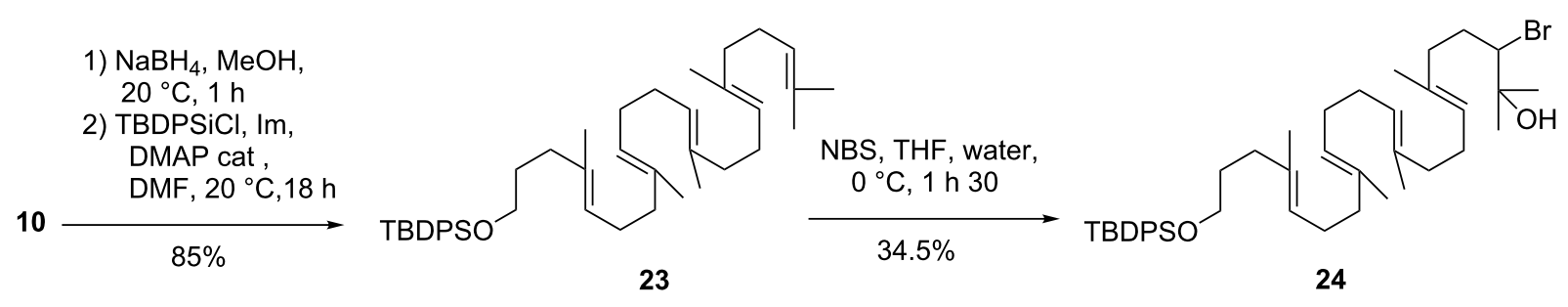

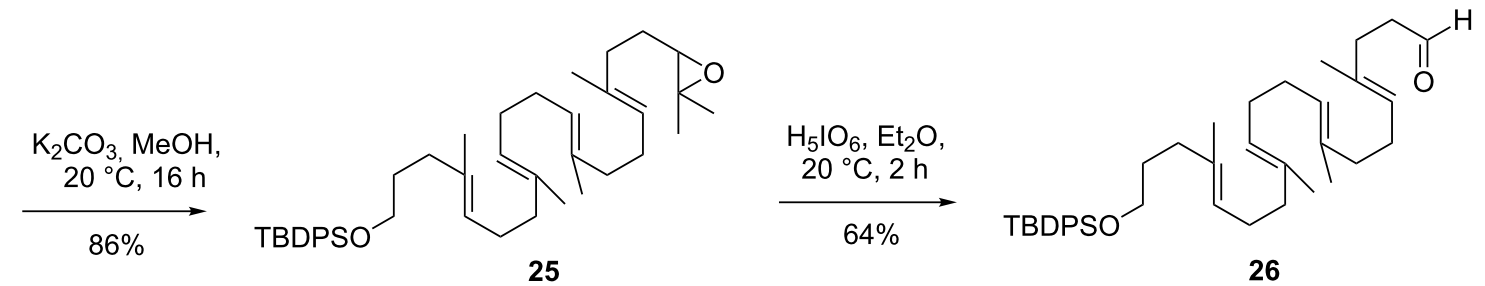

1) 14, $n$-BuLi, 2 equiv, DME, TMEDA

2) $-78^{\circ} \mathrm{C}$ to $0{ }^{\circ} \mathrm{C}, 3 \mathrm{~min}$

3) $26,-78^{\circ} \mathrm{C}, 1 \mathrm{~h}$

$63 \%$

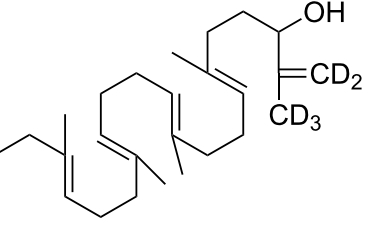

27
1) $\mathrm{SOCl}_{2}, \mathrm{Et}_{2} \mathrm{O}$, $0{ }^{\circ} \mathrm{C}, 4 \mathrm{~h}$ 2) $\mathrm{LiAID}_{4}, \mathrm{THF}$ reflux, $16 \mathrm{~h}$ $41 \%$

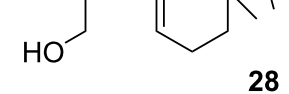

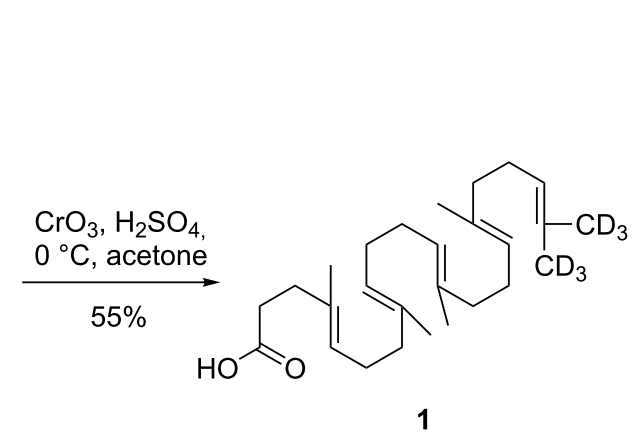

1) $\mathrm{ClCO}_{2} \mathrm{Et}, \mathrm{Et}_{3} \mathrm{~N}, \mathrm{THF}$ 2) 2, DMF, $20^{\circ} \mathrm{C}, 4 \mathrm{~d}$

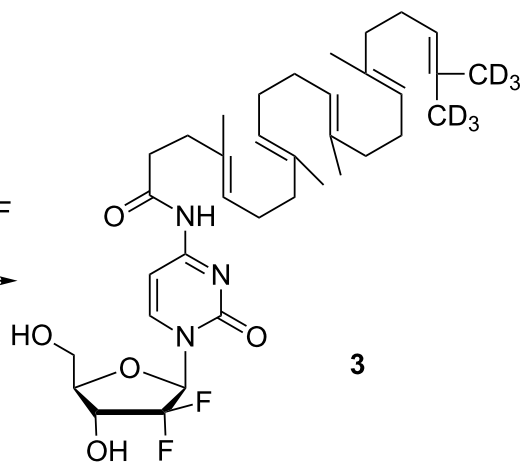

Scheme 4: Synthesis of squalenic acid- $d_{6} 1$ and conjugation to gemcitabine.

tial Raman probe. The use of this material as Raman probe in the study of the intracellular trafficking of GemSQ-based NAs is currently in progress and will be reported in due course.

\section{Experimental}

$(4 E, 8 E, 12 E, 16 E)-21-\left({ }^{2} \mathrm{H}_{3}\right)$ methyl-4,8,13,1 7-t etramethyl $\left(22,22,22-{ }^{2} \mathrm{H}_{3}\right)$ docosa-4,8,12,16,20-pentaenoic acid (1): An ice-cooled solution of alcohol 28 (55 mg, $0.14 \mathrm{mmol})$ in acetone $(2 \mathrm{~mL})$ was treated with a few drops of Jones reagent $\left(\mathrm{CrO}_{3} / \mathrm{H}_{2} \mathrm{SO}_{4} 6 \mathrm{M}\right)$ until the mixture took a persistent dark red color. After complete disappearance of the starting material a few drops of isopropanol were added. The mixture was taken into brine $(10 \mathrm{~mL})$ and extracted with $\mathrm{Et}_{2} \mathrm{O}(4 \times 15 \mathrm{~mL})$, dried over $\mathrm{MgSO}_{4}$ and concentrated under reduced pressure. The crude product was purified by chromatography over silica gel eluting with petroleum ether/ $\mathrm{Et}_{2} \mathrm{O} 80: 20$ to give trisnorsqualenic acid- $d_{6}(\mathbf{1})$ as a colorless oil $(31.5 \mathrm{mg}, 55 \%)$. ${ }^{1} \mathrm{H} \mathrm{NMR}\left(\mathrm{CDCl}_{3}, 300 \mathrm{MHz}\right) \delta 5.19-5.07(\mathrm{~m}, 5 \mathrm{H},=\mathrm{CH}), 2.45$ $\left(\mathrm{t}, J=7.6 \mathrm{~Hz}, 2 \mathrm{H}, \mathrm{CH}_{2} \mathrm{CO}_{2} \mathrm{H}\right), 2.30(\mathrm{t}, J=7.6 \mathrm{~Hz}, 2 \mathrm{H}$, $\left.\mathrm{CH}_{2} \mathrm{CH}_{2} \mathrm{CO}_{2} \mathrm{H}\right), 2.15-1.95\left(\mathrm{~m}, 16 \mathrm{H},=\mathrm{HCCH}_{2} \mathrm{CH}_{2} \mathrm{C}\left(\mathrm{CH}_{3}\right)\right)$, $1.62\left(\mathrm{~s}, 3 \mathrm{H},\left(\mathrm{CH}_{3}\right) \mathrm{C}=\right), 1.60\left(\right.$ br s, $\left.9 \mathrm{H},\left(\mathrm{CH}_{3}\right) \mathrm{C}=\right) ;{ }^{13} \mathrm{C} \mathrm{NMR}$ $\left(\mathrm{CDCl}_{3}, 75 \mathrm{MHz}\right) \delta 179.2\left(\mathrm{C}, \mathrm{CO}_{2} \mathrm{H}\right), 135.3\left(\mathrm{C}, \mathrm{CH}_{2}\left(\mathrm{CH}_{3}\right) \mathrm{C}=\right)$, $135.1\left(\mathrm{C}, \mathrm{CH}_{2}\left(\mathrm{CH}_{3}\right) \mathrm{C}=\right), 135.0\left(\mathrm{C}, \mathrm{CH}_{2}\left(\mathrm{CH}_{3}\right) \mathrm{C}=\right), 133.0(\mathrm{C}$, $\left.\mathrm{CH}_{2}\left(\mathrm{CH}_{3}\right) \mathrm{C}=\right), 131.2\left(\mathrm{C},\left(\mathrm{CD}_{3}\right)_{2} \mathrm{C}=\right), 125.5(\mathrm{CH}, \mathrm{HC}=), 124.6$ $(2 \mathrm{CH}, \mathrm{HC}=), 124.4(2 \mathrm{CH}, \mathrm{HC}=), 39.9\left(2 \mathrm{CH}_{2}\right), 39.7\left(\mathrm{CH}_{2}\right)$, $34.4\left(\mathrm{CH}_{2}, \mathrm{CH}_{2} \mathrm{CH}_{2} \mathrm{CO}_{2} \mathrm{H}\right), 33.0\left(\mathrm{CH}_{2}, \mathrm{CH}_{2} \mathrm{CO}_{2} \mathrm{H}\right), 28.4$ $\left(2 \mathrm{CH}_{2}\right), 26.9\left(\mathrm{CH}_{2}\right), 26.8\left(2 \mathrm{CH}_{2}\right), 16.1\left(3 \mathrm{CH}_{3}\right), 16.0\left(\mathrm{CH}_{3}\right) ; \mathrm{IR}$ (film, $\mathrm{cm}^{-1}$ ) v: 3500-2600 (broad), 2962, 2916, 2856, 2222, 

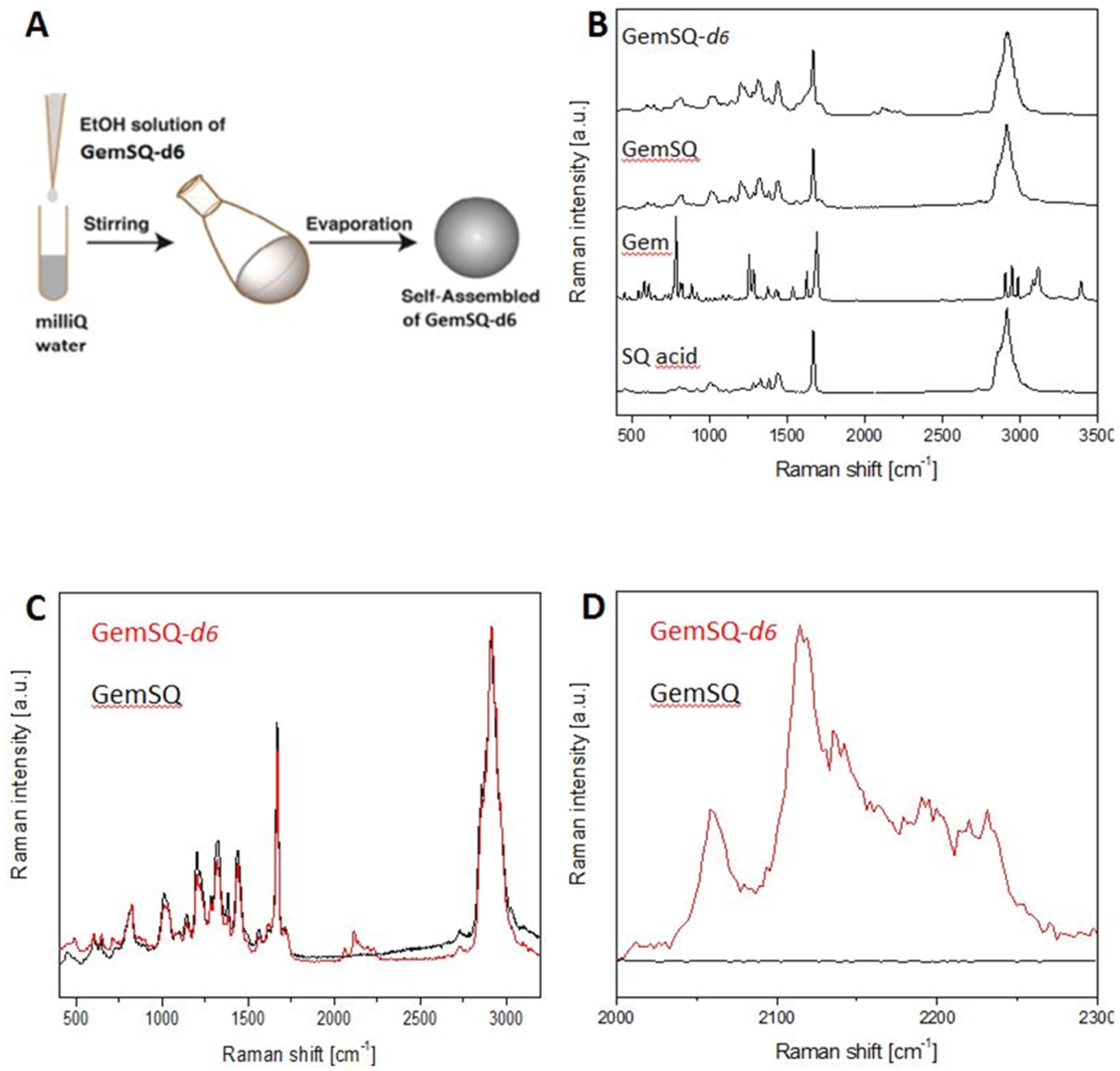

Figure 2: A) Sketch depicting the procedure of preparing the NAs. B) Single Raman spectra of GemSQ- $d_{6}$ NAs, GemSQ NAs, gemcitabine and squalenic acid, respectively. C) Single Raman spectra of deuterated GemSQ- $d_{6}$ NAs (red) and GemSQ NAs (black). D) Close-up showing the difference between deuterated and non-deuterated compounds.

2188, 1709, 1666, 1450, 1411, 1302, 1299, 1259, 1211, 1096, 1049, 955, 846, 736, 704; HRMS-ESI ${ }^{-}$: calcd for $\mathrm{C}_{27} \mathrm{H}_{37} \mathrm{D}_{6} \mathrm{O}_{2}$ : 405.3645; found: 405.3631 .

$(4 E, 8 E, 12 E, 16 E)-N-\{1-[(2 R, 5 R)-3,3-d i f l u o r o-4-h y d r o x y-5-$ (hydroxymethyl)oxolan-2-yl]-2-oxo-1,2-dihydropyrimidin-4yl\}-21- $\left({ }^{2} \mathrm{H}_{3}\right)$ methyl-4,8,13,17-tetramethyl $(22,22,22$ ${ }^{2} \mathbf{H}_{3}$ )docosa-4,8,12,16,20-pentaenamide (3): To a solution cooled at $-5{ }^{\circ} \mathrm{C}$ of trisnorsqualenic acid- $d_{6}(1)(31.5 \mathrm{mg}$, $0.077 \mathrm{mmol})$ in dry THF $(0.6 \mathrm{~mL})$ was sequentially added triethylamine $(60 \mathrm{mg}, 0.23 \mathrm{mmol})$ and ethyl chloroformate (10 $\mathrm{mg}, 0.093 \mathrm{mmol})$. The reaction mixture was stirred for $30 \mathrm{~min}$ at this temperature and a solution of gemcitabine base (60.6 $\mathrm{mg}, 0.23 \mathrm{mmol})$ in DMF $(2 \mathrm{~mL})$ was added. The reaction mixture was stirred for 4 days at $20^{\circ} \mathrm{C}$ and concentrated under reduced pressure. The residue was directly chromatographed over silica gel eluting with cyclohexane/AcOEt 4:1 followed by neat AcOEt to provide GemSQ- $d_{6}(3)$ as a colorless oil (36.0 mg, 72\%). ${ }^{1} \mathrm{H} \mathrm{NMR}\left(\mathrm{CDCl}_{3}, 400 \mathrm{MHz}\right) \delta 9.15$ (br s, $1 \mathrm{H}$, NHCO), 8.10 (d, $J=7.5 \mathrm{~Hz}, 1 \mathrm{H}, \mathrm{H}-6), 7.47$ (d, $J=7.5 \mathrm{~Hz}, 1 \mathrm{H}$,

$\mathrm{H}-5), 6.18$ (t, $\left.J=7.4 \mathrm{~Hz}, 1 \mathrm{H}, \mathrm{H}-1^{\prime}\right), 5.20-5.06(\mathrm{~m}, 5 \mathrm{H},=\mathrm{CH})$, 4.55-4.41 (m, 1H, H-3'), 4.15-3.95 (m, 3H, H-4', H-5', OH), $3.91(\mathrm{~d}, 1 \mathrm{H}, J=10.8 \mathrm{~Hz}, \mathrm{H}-5$ ') $2.55(2 \mathrm{H}, \mathrm{t}, J=7.6 \mathrm{~Hz}$, $\left.\mathrm{CH}_{2} \mathrm{CON}\right), 2.32\left(2 \mathrm{H}, \mathrm{t}, J=7.4 \mathrm{~Hz}, \mathrm{CH}_{2} \mathrm{CH}_{2} \mathrm{CON}\right), 2.10-1.91$ $\left(\mathrm{m}, 16 \mathrm{H},=\mathrm{CCH}_{2} \mathrm{CH}_{2} \mathrm{C}\left(\mathrm{CH}_{3}\right)\right), 1.60\left(3 \mathrm{H}, \mathrm{s},=\mathrm{C}\left(\mathrm{CH}_{3}\right)\right), 1.59(\mathrm{~s}$, $\left.6 \mathrm{H},=\mathrm{C}\left(\mathrm{CH}_{3}\right)\right), 1.58\left(3 \mathrm{H}, \mathrm{s},=\mathrm{C}\left(\mathrm{CH}_{3}\right)\right) ;{ }^{13} \mathrm{C} \mathrm{NMR}\left(\mathrm{CDCl}_{3}, 75\right.$ $\mathrm{MHz}) \delta 173.6(\mathrm{C}, \mathrm{CONH}), 163.1(\mathrm{C}, \mathrm{C}-4), 155.8$ (C, C-2), $145.6(\mathrm{CH}, \mathrm{C}-6), 135.3\left(\mathrm{C},\left(\mathrm{CH}_{3}\right) \mathrm{C}=\mathrm{CH}_{2}\left(\mathrm{CH}_{3}\right) \mathrm{C}=\right), 135.0(2 \mathrm{C}$, $\left.\mathrm{CH}_{2}\left(\mathrm{CH}_{3}\right) \mathrm{C}=\right), 132.8\left(\mathrm{C}, \mathrm{CH}_{2}\left(\mathrm{CH}_{3}\right) \mathrm{C}=\right), 131.2\left(\mathrm{C},\left(\mathrm{CD}_{3}\right)_{2} \mathrm{C}=\right)$, $126.0(\mathrm{CH}, \mathrm{HC}=), 124.5(2 \mathrm{CH}, \mathrm{HC}=), 124.4(2 \mathrm{HC}=), 122.5$ $\left(\mathrm{CF}_{2}, \mathrm{t}, J=258 \mathrm{~Hz}, \mathrm{C}-2{ }^{\prime}\right), 97.8$ (CH, C-5), $81.8\left(\mathrm{CH}, \mathrm{C}-4{ }^{\prime}\right)$, $69.3\left(\mathrm{CH}, \mathrm{m}, \mathrm{C}-3\right.$ '), $60.0\left(\mathrm{CH}_{2}, \mathrm{C}-5\right.$ ') $39.9\left(2 \mathrm{CH}_{2}\right), 39.7\left(\mathrm{CH}_{2}\right)$, 
$36.7\left(\mathrm{CH}_{2}, \mathrm{NHCOCH} \mathrm{CH}_{2}\right), 34.5\left(\mathrm{CH}_{2}, \mathrm{NHCOCH}_{2} \mathrm{CH}_{2}\right), 29.8$ $\left(\mathrm{CH}_{2}\right), 28.4\left(2 \mathrm{CH}_{2}\right), 27.0\left(\mathrm{CH}_{2}\right), 26.9\left(2 \mathrm{CH}_{2}\right), 26.8\left(2 \mathrm{CH}_{2}\right)$, $16.2\left(2 \mathrm{CH}_{3}\right), 16.1\left(\mathrm{CH}_{3}\right), 16.0\left(\mathrm{CH}_{3}\right)$; IR (film, $\left.\mathrm{cm}^{-1}\right) \mathrm{v}$ : 3500-3000 (broad), 2979, 2932, 2872, 2852, 2222, 2191, 1724, $1683,1660,1618,1561,1494,1433,1397,1383,1365,1337$, 1320, 1312, 1272, 1206, 1194, 1134, 1086, 1069, 1051, 915, 893, 813, 787, 738; HRMS-ESI ${ }^{-}$: calcd for $\mathrm{C}_{36} \mathrm{H}_{46} \mathrm{D}_{6} \mathrm{~N}_{3} \mathrm{O}_{5} \mathrm{~F}_{2}$ : 650.4257 ; found: 650.4230 .

Preparation of nanoassemblies from GemSQ and GemSQ$\boldsymbol{d}_{\mathbf{6}}$ : In a similar manner to the procedure published [19] the prodrugs based nanoparticle suspensions $\left(2 \mathrm{mg} \cdot \mathrm{mL}^{-1}\right)$ were prepared in a single step by dropwise addition of an ethanol solution $\left(4 \mathrm{mg} \cdot \mathrm{mL}^{-1}\right)$ in milli-Q water $(1 \mathrm{~mL})$ under vigorous stirring (500 rpm). Formation of NAs occurred immediately. After being stirred for $2 \mathrm{~min}$, the nanoparticle suspension was then transferred into a weighted round bottom flask and ethanol was evaporated using a Rotavapor with a preheated water bath $\left(35^{\circ} \mathrm{C}\right.$ ) setting the vacuum to about $15-50$ mbar for about $5 \mathrm{~min}$. Then, the flask was dipped into a water bath (water temperature $37{ }^{\circ} \mathrm{C}$ ) for about 3-5 minutes. Evaporation was continued till the weight of the contents decreased to $0.8-0.9 \mathrm{~g}$. Then, the volume of the suspension in the flask was made-up to $1.0 \mathrm{~g}$ using either $5 \%$ dextrose solution or milli-Q water. The colloidal dispersions were stored at $4{ }^{\circ} \mathrm{C}$.

Raman microscopy measurements. Confocal Raman microscopy measurements were performed with a WITec alpha 300R+ (WITec GmbH, Ulm, Germany). The excitation source was a diode laser with a wavelength of $532 \mathrm{~nm}$ adjusted to a power of $40 \mathrm{~mW}$ before the objective. A confocal pinhole of $50 \mu \mathrm{m}$ rejected signals from out-of-focus regions. An objective with $50 \times$ magnification (N.A. 0.8, Epiplan Neofluar, Zeiss, Germany) was applied for acquiring single Raman spectra of the pure compounds with an integration time of $2 \mathrm{~s}$ and $10 \mathrm{accu}-$ mulations. All spectra were background subtracted and normalized to the most intense peak.

\section{Supporting Information}

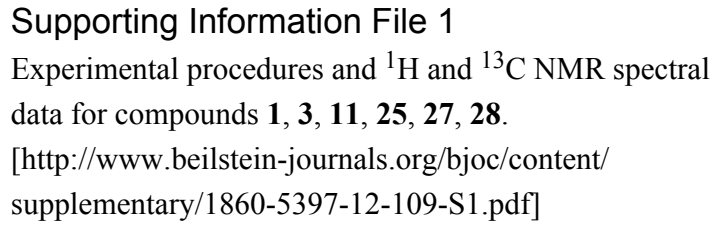

\section{Acknowledgements}

The research leading to these results has received funding from the European Research Council under the European Community's Seventh Framework Program FP7/2007-2013 Grant
Agreement no.249835. The financial supports of the Ministère de la Recherche et de la Technologie (fellowship to E.B.) is gratefully acknowledged.

\section{References}

1. Koo, O. M.; Rubinstein, I.; Onyuksel, H. Nanomed.: Nanotechnol. Biol. Med. 2005, 1, 193-212. doi:10.1016/j.nano.2005.06.004

2. Farokhzad, O. C.; Langer, R. ACS Nano 2009, 3, 16-20. doi:10.1021/nn900002m

3. Müller, R. H.; Mehnert, W.; Lucks, J. S.; Schwarz, C.; Mühlen, Z.; Weyhers, H.; Freitas, C.; Rühl, D. Eur. J. Pharm. Biopharm. 1995, 41, 62-69.

4. Olbrich, C.; Gessner, A.; Kayser, O.; Müller, R. H. J. Drug Targeting 2002, 10, 387-396. doi:10.1080/1061186021000001832

5. Desmaële, D.; Gref, R.; Couvreur, P. J. Controlled Release 2012, 161, 609-618. doi:10.1016/j.jconrel.2011.07.038

6. Burris, H. A., III; Moore, M. J.; Andersen, J.; Green, M. R.; Rothenberg, M. L.; Modiano, M. R.; Cripps, M. C.; Portenoy, R. K.; Storniolo, A. M.; Tarassoff, P.; Nelson, R.; Dorr, F. A.; Stephens, C. D.; Von Hoff, D. D. J. Clin. Oncol. 1997, 15, 2403-2413.

7. Couvreur, P.; Stella, B.; Reddy, L. H.; Hillaireau, H.; Dubernet, C.; Desmaële, D.; Lepêtre-Mouelhi, S.; Rocco, F.; Dereuddre-Bosquet, N.; Clayette, P.; Rosilio, V.; Marsaud, V.; Renoir, J.-M.; Cattel, L. Nano Lett. 2006, 6, 2544-2548. doi:10.1021/nI061942q

8. Reddy, L. H.; Renoir, J.-M.; Marsaud, V.; Lepetre-Mouelhi, S.; Desmaële, D.; Couvreur, P. Mol. Pharmaceutics 2009, 6, 1526-1535. doi:10.1021/mp900099e

9. Reddy, L. H.; Ferreira, H.; Dubernet, C.; Mouelhi, S. L.; Desmaële, D.; Rousseau, B.; Couvreur, P. Anti-Cancer Drugs 2008, 19, 999-1006. doi:10.1097/CAD.0b013e3283126585

10. Reddy, L. H.; Marque, P.-E.; Dubernet, C.; Lepêtre Mouelhi, S.; Desmaële, D.; Couvreur, P. J. Pharmacol. Exp. Ther. 2008, 325, 484-490. doi:10.1124/jpet.107.133751

11. Réjiba, S.; Reddy, L. H.; Bigand, C.; Parmentier, C.; Couvreur, P.; Hajri, A. Nanomedicine 2011, 7, 841-849. doi:10.1016/j.nano.2011.02.012

12. Gourdeau, H.; Clarke, M. L.; Ouellet, F.; Mowles, D.; Selner, M.; Richard, A.; Lee, N.; Mackey, J. R.; Young, J. D.; Jolivet, J.; Lafrenière, R. G.; Cass, C. E. Cancer Res. 2001, 61, 7217-7224.

13. Kim, M. P.; Gallick, G. E. Clin. Cancer Res. 2008, 14, 1284-1285. doi:10.1158/1078-0432.CCR-07-2247

14. Hillaireau, H.; Dereuddre-Bosquet, N.; Skanji, R.; Bekkara-Aounallah, F.; Caron, J.; Lepêtre, S.; Argote, S.; Bauduin, L.; Yousfi, R.; Rogez-Kreuz, C.; Desmaële, D.; Rousseau, B.; Gref, B.; Andrieux, K.; Clayette, P.; Couvreur, P. Biomaterials 2013, 34, 4831-4838. doi:10.1016/j.biomaterials.2013.03.022

15. Raouane, M.; Desmaele, D.; Gilbert-Sirieix, M.; Gueutin, C.; Zouhiri, F.; Bourgaux, C.; Lepeltier, E.; Gref, R.; Ben Salah, R.; Clayman, G.; Massaad-Massade, L.; Couvreur, P. J. Med. Chem. 2011, 54, 4067-4076. doi:10.1021/jm2000272

16. Gaudin, A.; Yemisci, M.; Eroglu, H.; Lepêtre-Mouelhi, S.; Turgoglu, O. F.; Dönmez-Demir, B.; Caban, S.; Fevzi Sargon, M.; Garcia-Argote, S.; Pieters, G.; Loreau, O.; Rousseau, B.; Tagit, O.; Hildebrandt, N.; Le Dantec, Y.; Mougin, J.; Valetti, S.; Chacun, H.; Nicolas, V.; Desmaële, D.; Andrieux, K.; Capan, Y.; Dalkara, T.; Couvreur, P. Nat. Nanotechnol. 2014, 9, 1054-1062. doi:10.1038/nnano.2014.274 
17. Sémiramoth, N.; Di Meo, C.; Zouhiri, F.; Saïd-Hassane, F.; Valetti, S.; Gorges, R.; Nicolas, V.; Poupaert, J. H.; Chollet-Martin, S.; Desmaële, D.; Gref, R.; Couvreur, P. ACS Nano 2012, 6, 3820-3831. doi:10.1021/nn204928v

18. Caron, J.; Maksimenko, A.; Wack, S.; Lepeltier, E.; Bourgaux, C.; Morvan, E.; Leblanc, K.; Couvreur, P.; Desmaële, D. Adv. Healthcare Mater. 2013, 2, 172-185. doi:10.1002/adhm.201200099

19. Buchy, E.; Valetti, S.; Mura, S.; Mougin, J.; Troufflard, C.; Couvreur, P.; Desmaële, D. Eur. J. Org. Chem. 2015, 202-212. doi:10.1002/ejoc.201403088

20. Maksimenko, A.; Dosio, F.; Mougin, J.; Ferrero, A.; Wack, S.; Reddy, L. H.; Weyn, A.-A.; Lepeltier, E.; Bourgaux, C.; Stella, B.; Cattel, L.; Couvreur, P. Proc. Natl. Acad. Sci. U. S. A. 2014, 111, E217-E226. doi:10.1073/pnas.1313459110

21. Bildstein, L.; Marsaud, V.; Chacun, H.; Lepêtre-Mouelhi, S.; Desmaële, D.; Couvreur, P.; Dubernet, C. Soft Matter 2010, 6, 5570-5580. doi:10.1039/C0SM00342E

22. Gaudin, A.; Lepetre-Mouelhi, S.; Mougin, J.; Parrod, M.; Pieters, G.; Garcia-Argote, S.; Loreau, O.; Goncalves, J.; Chacun, H.; Courbebaisse, Y.; Clayette, P.; Desmaële, D.; Rousseau, B.; Andrieux, K.; Couvreur, P. J. Controlled Release 2015, 212, 50-58. doi:10.1016/j.jconrel.2015.06.016

23. Li, Y.; Budamagunta, M. S.; Luo, J.; Xiao, W.; Voss, J. C.; Lam, K. S. ACS Nano 2012, 6, 9485-9495. doi:10.1021/nn302317j

24. Antonio, K. A.; Schultz, Z. D. Anal. Chem. 2014, 86, 30-46. doi:10.1021/ac403640f

25. Kann, B.; Offerhaus, H. L.; Windbergs, M.; Otto, C. Adv. Drug Delivery Rev. 2015, 89, 71-90. doi:10.1016/j.addr.2015.02.006

26. Mendelsohn, R.; Sunder, S.; Berstein, H. J. Biochim. Biophys. Acta 1976, 443, 613-617.

27. Stiebing, C.; Matthäus, C.; Krafft, C.; Keller, A.-A.; Weber, K.; Lorkowski, S.; Popp, J. Anal. Bioanal. Chem. 2014, 406, 7037-7046. doi:10.1007/s00216-014-7927-0

28. Hauptfleisch, R.; Franck, B. Tetrahedron Lett. 1997, 38, 383-386. doi:10.1016/S0040-4039(96)02332-5

29. West, R.; Wang, Y.; Atkinson, J. J. Labelled Compd. Radiopharm. 2008, 51, 413-418. doi:10.1002/jlcr.1554

30. van Tamelen, E. E.; Curphey, T. J. Tetrahedron Lett. 1962, 3, 121-124. doi:10.1016/S0040-4039(00)71112-9

31. Morimoto, Y.; Takeuchi, E.; Kambara, H.; Kodama, T.; Tachi, Y.; Nishikawa, K. Org. Lett. 2013, 15, 2966-2969. doi:10.1021/ol401081e

32. Murray, D. F. J. Org. Chem. 1983, 48, 4860-4864. doi:10.1021/jo00173a015

33. Schlosser, M.; Schaub, B. Chimia 1982, 36, 396-397.

34. Shapiro, R. H.; Heath, M. J. J. Am. Chem. Soc. 1967, 89, 5734-5735. doi:10.1021/ja00998a601

35. Surendra, K.; Corey, E. J. J. Am. Chem. Soc. 2008, 130, 8865-8869. doi:10.1021/ja802730a

36. Faulkner, D. J.; Petersen, M. R. J. Am. Chem. Soc. 1973, 95, 553-563. doi:10.1021/ja00783a040

37. Kim, K. S.; Song, Y. H.; Lee, B. H.; Hahn, C. S. J. Org. Chem. 1986, 51, 404-407. doi:10.1021/jo00353a027

38. Honda, Y.; Ori, A.; Tsuchihashi, G. Chem. Lett. 1987, 16, 1259-1962. doi:10.1246/cl.1987.1259

39. Rajashekhar, B.; Kaiser, E. T. J. Org. Chem. 1985, 50, 5480-5484. doi:10.1021/jo00350a007

\section{License and Terms}

This is an Open Access article under the terms of the Creative Commons Attribution License

(http://creativecommons.org/licenses/by/2.0), which permits unrestricted use, distribution, and reproduction in any medium, provided the original work is properly cited.

The license is subject to the Beilstein Journal of Organic Chemistry terms and conditions:

(http://www.beilstein-journals.org/bjoc)

The definitive version of this article is the electronic one which can be found at:

doi:10.3762/bjoc. 12.109 